\title{
$\Psi$
}

\section{Pengaruh Terapi Membatik terhadap Depresi pada Narapidana}

\begin{abstract}
ABSTRAK Penelitian ini bertujuan untuk mengetahui sejauhmana pengaruh terapi membatik terhadap tingkat depresi pada narapidana. Penelitian ini menggunakan kerangka teori empat simtom depresi dari Beck (1985) yang telah divalidasi dalam berbagai konteks budaya. 30 narapidana dari Rumah Tahanan Kelas II B Rembang - Jawa Tengah yang memiliki skor depresi tinggi dan bersedia menjadi subjek dibagi kedalam kelompok eksperimen dan kelompok kontrol. Subjek kemudian diminta untuk mengisi Beck Depression Inventory (BDI) sebanyak tiga kali yaitu sebelum terapi (pretest), sesaat setelah terapi (posttest) dan 2 minggu setelah terapi (follow up) serta diminta untuk menuliskan perkembangan emosinya selama terapi. Data dalam penelitian berupa data kuantitatif yang dilengkapi dengan data kualitatif untuk menguatkan penjelasan proses terapi, khususnya dari sisi subjek. Data kuantitatif kemudian dianalisis dengan Wilcoxon signed rank dengan bantuan program SPSS. Hasil penelitian menunjukkan bahwa pada

kelompok eksperimen terdapat perbedaan yang sangat signifikan antara skor depresi pada saat posttest dibandingkan dengan saat pretest ( $p=0.001$ ), sedangkan

pada kelompok kontrol tidak ada perbedaan skor yang signifikan ( $p=0.824)$. Mengenai hasil-hasil temuan penelitian tersebut akan dipaparkan secara lebih luas di dalam diskusi.
\end{abstract}

KATA KUNCI: Terapi membatik, Narapidana, Depresi, BDI

\section{Akhmad Mukhlis}

Dosen Sekolah Tinggi Agama Islam Al-Kamal Sarang Rembang

Email:muchel.akhmad@gmail.com

PSIKOISLAMIKA, Jurnal Psikolog̣ł Islairh(JPI) Copyright ( 2011 Lembaga Penelitian Pengembangan da - 'aislaman(LPKK). Ptô.12011 99-116 


\section{Muqadimah}

Indonesia merupakan salah satu negara dengan tingkat kriminalitas tinggi, hal tersebut dapat dilihat dari semakin meningkatnya jumlah narapidana dalam Lembaga Pemasyarakatan (LP). Disi lain, data terakhir dinas Direktur Jenderal Pemasyarakatan Indonesia menyatakan bahwa kepadatan Lapas telah menyentuh 162.22\% (Grafik Rata-Rata Pertahun Jumlah Narapidana Pada Lapas dan Rutan Seluruh Indonesia, November 2010). Artinya jumlah penghuni hampir dua kali lipat dari Lapas yang disediakan. Jika tidak ditangani dengan tepat, hal tersebut akan menimbulkan permasalahan di kemudian hari.

Menjadi narapidana adalah stresor kehidupan yang berat bagi pelakunya. Perasaan sedih pada narapidana setelah menerima hukuman serta berbagai hal lainnya seperti rasa bersalah, hilangnya kebebasan, perasaan malu, sangsi ekonomi dan sosial serta kehidupan dalam penjara yang penuh dengan tekanan psikologis dapat memperburuk dan mengintensifkan stresor sebelumnya. Keadaan tersebut bukan saja mempengaruhi penyesuaian fisik tetapi juga psikologis individu (Morgan, 1981; Gussak 2009).

Penyebab terjadinya gangguan psikologis dapat berasal dari individu baik kondisi fisik (misalnya sakit) dan psikologis (misalnya konflik, prosesi persidangan, dan vonis hukum), maupun berasal dari sosial (misalnya interaksi anggota keluarga, tekanan pekerjaan dan ekonomi), serta dapat juga berasal dari komunitas atau lingkungan (misalnya sekolah, penjara dan kejadian-kejadian kompetitif) (Coleman, 1991; Mazure, 1998; Gussak, 2009).

Sebuah studi berkelanjutan mulai tahun 2003 sampai 2009 di Florida menyatakan bahwa depresi merupakan salah satu masalah utama dalam penjara, sebanyak 25\% narapidana diindikasikan menderita depresi berat, sedangkan 30\% lainnya diindikasikan menderita depresi ringan sampai sedang (Gussak, 2009).

\section{Kerangka Kerja Teoritik}

Depresi adalah gangguan psikologis dengan menurunnya suasana hati (mood), optimisme, konsentrasi dan motivasi serta kesedihan mendalam dengan menyalahkan diri sendiri yang disebabkan oleh berkembangnya pemikiran tidak logis dan mendominasi pola-pola kognitif (Beck, 1985 Horowitz \& Garber, 
2006). Hal tersebut akan menimbulkan penderitaan dalam satu atau lebih fungsi yang dianggap penting dalam hidup manusia seperti; perilaku, psikologis, biologis, serta hubungan manusia dengan lingkungan sosialnya (Hawton et al. 1993; Horowitz \& Garber, 2006).

Teori dan hasil penelitian sejauh ini sepakat secara esensial bahwa gejala pada gangguan depresi dapat berupa gejala dalam gaya berpikir (kognitif), dalam hal perasaan dan juga gejala yang terlihat dalam fisik baik psikomotor ataupun psikosomatis (Beck, 1985; Wilkinson, 1992; De Clerq, 1994; APA, 2003; Garnefsky et al, 2002; Bilkser et al, 2006). Oleh beberapa ahli, gejala tersebut diatas sering disebut gejala primer. Terdapat juga gejala sekunder yang sering ditemukan bersamaan dengan gejala primer, meskipun gejala sekunder tidak selalu terjadi pada setiap penderita depresi. Gejala sekunder biasanya berupa masalah hubungan, masalah pekerjaan, masalah tingkah laku, keluhan somatis dan juga kecemasan (De Wit dalam De Clerq, 1994; Greenberger \& Padesky, 1995).

Terkait bagaimana depresi dapat muncul menjadi gangguan pada individu, Retnowati (2008) mengemukakan bahwa hal tersebut dikarenakan terdapat faktor-faktor pengantar dengan kejadian yang menekan. Faktor tersebut adalah 1) sumber daya pribadi berupa pola pikir negatif, harga diri rendah, dan pola kendali diri rendah terhadap stresor. 2) Sumber daya sosial berupa dukungan sosial dan juga 3) bagaimana strategi mengatasi masalah adaptif pada setiap individu.

Depresi dapat dikategorikan menjadi tiga jenis, yaitu depresi ringan, depresi somatik dan depresi non-somatik (Silverstein dan Blumenthal, 1997; Silverstein dan Lynch, 1998; Silverstein, 2002). Seseorang dikatakan mengalami depresi ringan apabila memiliki intensitas depresi rendah (ditunjukkan dalam hasil pengukuran dengan skala depresi). Depresi somatik terjadi apabila seseorang mengalami depresi dengan intensitas tinggi dan disertai oleh gejala somatik, yaitu gangguan nafsu makan, gangguan tidur, dan kelelahan. Depresi murni (nonsomatik) terjadi apabila seseorang mengalami gejala depresi dengan intensitas tinggi tanpa disertai gejala somatik atau keluhan fisik Rata-rata episode depresif dapat didiagnosis dalam waktu dua minggu. Dalam penelitian ini, kategorisasi depresi akan didasarkan oleh data yang diperoleh dari pengukuran dengan

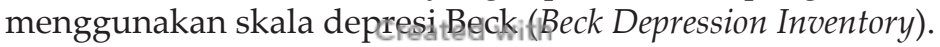


Perkembangan ilmu psikologi membuka berbagai ruang baru dalam memberikan berbagai alternatif terkait intervensi gangguan psikologis, salah satunya berupa art therapy (terapi seni). Case \& Dalley (1992) dalam Hand Book of Art Therapy mengatakan bahwa art therapy adalah jenis terapi dengan menggunakan beberapa media seni sebagai intervensinya, sehingga pasien atau klien dapat berekspresi dan bekerja melalui permasalahan dan perhatiannya. The American Art Therapy Association (2000) mengatakan bahwa terapi seni banyak digunakan sebagai sarana menyelesaikan konflik emosional, meningkatkan kesadaran diri, mengembangkan ketrampilan sosial, mengontrol perilaku, menyelesaikan permasalahan, mengurangi kecemasan, mengerahkan realitas, meningkatkan harga diri dan berbagai gangguan psikologis lainnya. Tujuan terapi jenis ini lebih menekankan pada kebebasan komunikasi daripada menghasilkan bentuk (hasil karya) artistik (Case \& Dalley, 1992; Ballou, 1995; Huss, 2009; Gussak, 2009).

Terapi seni merupakan salah satu jenis dari berbagai jenis terapi ekspresif melibatkan individu dalam aktivitas kreatif dalam bentuk penciptaan (karya atau produk) seni (Case \& Dalley, 1992; Ballou, 1995). Melalui aktifitas seni tersebut individu diasumsikan mendapat media paling aman untuk memfasilitasi komunikasi melalui eksplorasi pikiran, persepsi, keyakinan, dan pengalaman, khususnya emosi (Holt \& Kaiser, 2009). Proses dan respon subjek saat menggambar serta karya seni subjek digunakan sebagai refleksi atas perkembangan, kemampuan, kepribadian, ketertarikan, perhatian dan konflik individu (Ballou, 1995; Glaister, 2000).

Seperti halnya jenis terapi lain, terapi seni dapat dilakukan dengan intensif ataupun jangka waktu panjang. Hal tersebut disesuaikan dengan kepentingan dan tujuan penelitian. Waktu yang dibutuhkan dalam terapi dalam jangka panjang biasanya berkisar antara 3 bulan sampai 1 tahun (Wallin dan Durr, 2002; Huss, 2009 dan Gussak, 2009) sedangkan untuk terapi dalam jangka pendek biasanya dilakukan tidak lebih dalam 12 sesi (Malchiodi, 1997; Johnson, 2001).

Terkait teknik dalam terapi seni, sebagian besar digolongkan menjadi teknik terstruktur dan tidak terstruktur (Case \& Dalley, 1992). Pada teknik terstruktur, subjek diminta untuk menggambar image yang telah ditentukan. Prosesdnterpretasi pada teknik ini berdasarkan kriteria tertentu seperti tolanan, penggunaapd 
bentuk, pemberian bayangan dan lain sebagainya. Pada teknik tidak terstruktur, subjek diberikan kebebasan sepenuhnya dan interpretasi gambar tidak berdasarkan kriteria baku (Ballou, 1995; Lantz \& Lisa, 2003).

Hal ini mendorong peneliti untuk melakukan penelitian dengan menggunakan seni sebagai intervensi terapi untuk narapidana dengan gangguan depresi. Seni yang digunakan dalam penelitian ini adalah batik (membatik). Batik adalah budaya bangsa Indonesia yang telah diakui dunia sekaligus budaya khas pada lokasi penelitian yaitu Lasem-Rembang, maka kemungkinan penerimaan subjek akan lebih baik daripada intervensi dengan modalitas lainnya. Hal tersebut sejalan dengan pendapat Riley (dalam Wallin \& Durr, 2002) bahwa agar suatu intervensi atau terapi dapat berjalan efektif maka harus menggunakan metode sesuai dan dapat diterima oleh subjek. Bahkan menggambar memberi cara untuk mengekspresikan pikiran dan perasaan individu dengan sedikit perasaan terancam dibandingkan komunikasi verbal (Malchiodi, 1988; Malchiodi, 2001; Case \& Dalley, 1992). Dengan diterimanya metode terapi maka akan menurunkan tingkat resistensi subjek terhadap terapi dan berpengaruh positif terhadap proses terapeutik (Malchiodi, 2003).

Sebagai salah satu jenis seni, pada dasarnya membatik memiliki tahapan yang telah dikembangkan oleh beberapa terapis sebagai modalitas terapi seni, yaitu menggambar. Namun dalam berbagai sudut, membatik bukan semata-mata menggambar biasa. Karena membatik melibatkan lebih banyak faktor dan sarana dibandingkan dengan menggambar biasa seperti penggunaan lilin cair, canting, dan proses pewarnaan.

Sebagai bagian dari terapi seni, secara garis besar terapi membatik memiliki fungsi sama dengan fungsi terapi seni, yaitu sarana untuk menyelesaikan konflik emosional, meningkatkan kesadaran diri, mengembangkan ketrampilan sosial, mengontrol perilaku, menyelesaikan permasalahan, mengurangi kecemasan, mengarahkan realitas dan meningkatkan self esteem (Case \& Dalley, 1992).

Secara faali, menggambar dikontrol oleh sistim kortikal yang tidak sepenuhnya tumpang tindih. Terdapat minimal dua sistem korteks serebral yang setidaknya berperan dalam aktifitas menggambar, yaitu padaalobuwit frontal dan lobus parietal (Solso, 
et al., 2008; Sternberg, 2008). Lobus frontal secara umum terlibat dalam pengendalian impuls, pertimbangan, pemecahan masalah, pengendalian dan pelaksanaan perilaku dan pengorganisasian kompleks. Dalam aktifitas menggambar, sistem ini terlibat penuh dalam pengendalian pergerakan tangan dalam menggambar dan penggerakan canting. Lobus parietal dalam aktivitas menggambar berperan dalam pengintegrasian sensor dari pancaindera dan abstraksi (manipulasi) objek dalam pemrosesan visual gambar yang akan dibuat.

Simbol-simbol gambar umumnya memberikan kesempatan pada individu untuk mengekspresikan perasaan serta emosinya sehingga memberikan kepuasan pada individu (Malchiodi, 2001; Huss, 2009; Gussak; 2009). Dalam teori Freud hal tersebut sering disebut sebagai sublimasi. Asumsi Freud adalah bahwa sublimasi libido yang tidak terpuaskan merupakan sumber inspirasi bagi terciptanya semua seni (Case \& Dalley, 1992). Ia menganggap bahwa seniman menyalurkan semua seksualitas masa kanak-kanaknya dengan mengubahnya ke dalam bentuk yang sifatnya tidak naluriah. Insting manusia dipercaya Freud mendorong lahirnya kreativitas yang mengarah pada sebuah tujuan (biasanya seksual atau libidinal, dan agresif) dan pada objek (seseorang atau suatu tujuan). Kelainan atau penyimpangan (perversi) histeria, psikosa dan seksual dapat dihindari jika terdapat saluran pengalihan (sublimasi) sebagaimana dimiliki seniman dengan kegiatan kreatifnya. Dalam proses inilah seniman mengendalikan fantasi, ambisi, dan dorongan seksualnya ke dalam kegiatan kreatif.

Dalam ranah sosial, terdapat fakta menarik terkait membatik dan leisure. Leisure diartikan bagaimana individu menggunakan waktu luangnya, apa yang individu lakukan untuk berelaksasi, aktivitasaktivitas yang lakukan idividu untuk memperoleh kesenangan, dan bagaimana individu menyalurkan hasrat dan minatnya (Snyder \& Lopez, 2007). Selanjutnya Snyder \& Lopez (2007) juga menyebutkan leisure sebagai aktivitas yang dapat menaikkan well being seseorang karena bermakna bagi orang tersebut, memberikan kebebasan, merupakan sarana untuk keluar dari rutinitas sehari-hari, dan menjadi sarana untuk bersosialisasi dengan orang lain.

Dari penjelasan diatas, hipotesis yang diajukan dalam penelitian ini adalah terapidmembatik dapat menurunkan tingkat depresi pada narapidana

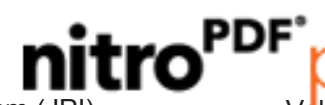




\section{Metode}

Penelitian ini menggunakan metode kuasi-eksperimen model untreated control group design with pre-test and post-test (Shadish et al., 2002), dengan membagi subjek secara random ke dalam kelompok eksperimen dan kelompok kontrol. Sebanyak 30 narapidana dengan skor depresi sedang sampai berat. Subjek diutamakan sebagai narapidana baru dan telah memiliki keluarga (telah menikah). Penelitian ini menggunakan Beck Depression Inventory (BDI) versi bahasa Indonesia yang diadaptasi dari BDI bahasa Inggris. Uji realibilitas skala menunjukkan bahwa skala BDI cukup reliabel (Hoyt $\alpha=0,844$ ). Dalam prosedur penyajiannya, pertama, responden diminta untuk merespon 21 aitem kelompok pernyataan yang merepresentasikan 4 simtom depresi (Beck, 1985). Pengambilan data menggunakan skala dilakukan tiga kali, yaitu sebelum terapi (pretest), sesaat setelah terapi (posttest 1) dan 2 minggu setelah pengukuran kedua (posttest 2). Data dari skala dilengkapi dengan observasi, wawancara yang bersifat terbuka (open-ended responses), dan hasil karya seni batik subjek.

\section{Manipulasi}

Variabel independen dalam penelitian ini adalah terapi membatik. Secara konseptual, terapi membatik adalah adaptasi dari terapi seni Ballou (1995) dengan menggunakan sesi membatik dari hasil konsultasi dengan ahli batik Lasem Santoso Hartono. Sesi terapi terdiri dari 7 sesi, 4 hari dalam rentang waktu seminggu. 7 sesi tersebut terdiri dari sesi materi dan sesi praktek. Sesi materi difasilitatori oleh ahli dalam bidangnya. Sesi praktek difasilitatori oleh ahli dalam menggambar dan membatik.

\section{Hasil}

Dari hasil uji normalitas menggunakan teknik One-Sample Kolmogorov-Smirnov Test pada skala depresi (Beck Depression Inventory) didapatkan hasil pre-test $=0.026$, post-test $1=0.964$ dan post-test $2=0.862$. Sesuai dengan kaidah yang digunakan yaitu $\mathrm{p}>0.05$, maka skor skala depresi selain pada saat pre-test memiliki sebaran normal.

Uji homogenitas varians menggunakan teknik Homogenity of Variance One Way Anova. Dari hasil uji Lavene Statistic skala depresi menunjukkan nilai signifika 
0.320 , dan post-test $2=0.187$. Sesuai kaidah yang digunakan, maka ketiga nilai pemberian skala tersebut memiliki varians homogen atau sama.

Analisis data yang dilakukan menggunakan uji sampel berpasangan Wilcoxon baik dalam kelompok eksperimen ataupun antara kelompok eksperimen dan kelompok kontrol dengan taraf signifikansi $\mathrm{p}<0.05$ adalah sebagai berikut:

1. Hasil uji skala BDI dalam kelompok eksperimen

a. Hasil analisa skor pre-test dan post-test 1 skala depresi pada kelompok eksperimen menunjukkan bahwa nilai $\mathrm{p}$ $=0.001$. Artinya, terdapat penurunan skor depresi secara signifikan.

b. Hasil analisa skor pre-test 1 dan post-test 2 skala depresi pada kelompok eksperimen menunjukkan bahwa nilai $\mathrm{p}=0.909$. Artinya tidak terdapat penurunan skor depresi secara siginifikan.

2. Hasil uji skala BDI antara kelompok eksperimen dan kelompok kontrol

c. Hasil analisa skor posttest 1 menunjukkan bahwa nilai $\mathrm{p}$ $=0.001$. Artinya, terdapat penurunan skor depresi secara signifikan pada kelompok eksperimen dibandingkan kelompok kontrol.

d. Hasil analisa skor posttest 2 menunjukkan bahwa nilai $\mathrm{p}$ $=0.001$. Artinya, terdapat penurunan skor depresi secara signifikan pada kelompok eksperimen dibandingkan kelompok kontrol.

Berikut adalah tabel rangkuman hasil uji sampel berpasangan Wilcoxon:

Tabel 1. Rangkuman hasil uji sampel berpasangan Wilcoxon

\begin{tabular}{|c|c|c|c|c|}
\hline Kelompok & Pasangan uji & $\mathrm{Z}$ & $\mathrm{p}$ & Keterangan \\
\hline \multirow{2}{*}{ Eksperimen } & $\begin{array}{c}\text { Skor pre-test } \\
\text { dan post-test 1 }\end{array}$ & $-3.415^{\mathrm{a}}$ & 0.001 & Signifikan \\
\cline { 2 - 5 } & $\begin{array}{c}\text { Skor post-test 1 } \\
\text { dan post-test 2 }\end{array}$ & $-.114^{\mathrm{a}}$ & 0.909 & Tidak signifikan \\
\hline \multicolumn{4}{|c}{ Created with } \\
\hline
\end{tabular}

\section{n nitro ${ }^{\text {PDF }}$}




\begin{tabular}{|c|c|c|c|c|}
\hline $\begin{array}{c}\text { Kelompok } \\
\text { eksperimen } \\
\text { dengan } \\
\text { kontrol }\end{array}$ & Skor post-test 1 & $-3.411^{\mathrm{b}}$ & 0.001 & Signifikan \\
\cline { 2 - 5 } & Skor post-test 2 & $-3.240^{\mathrm{b}}$ & 0.001 & Signifikan \\
\hline
\end{tabular}

Untuk lebih menjelaskan hasil uji diatas, berikut adalah skor rata-rata (mean) skala BDI pada kelompok eksperimen dan kelompok kontrol beserta kategorisasinya:

Tabel 2. Data rata-rata (mean) BDI kelompok eksperimen dan kelompok kontrol

\begin{tabular}{|c|c|c|c|c|c|c|}
\hline $\begin{array}{c}\text { Kelom- } \\
\text { pok }\end{array}$ & $\begin{array}{c}\text { BDI } \\
\text { pretest }\end{array}$ & $\begin{array}{c}\text { Kat- } \\
\text { egori }\end{array}$ & $\begin{array}{c}\text { BDI } \\
\text { posttes1 }\end{array}$ & $\begin{array}{c}\text { Kate- } \\
\text { gori }\end{array}$ & $\begin{array}{c}\text { BDI post- } \\
\text { test2 }\end{array}$ & Kategori \\
\hline $\begin{array}{c}\text { Eksperi- } \\
\text { men }\end{array}$ & 37.333 & Berat & 18.933 & Ringan & 18.666 & Ringan \\
\hline Kontrol & 34.266 & Berat & 33.9333 & Berat & 31.1333 & Berat \\
\hline
\end{tabular}

Berikut adalah grafik berdasarkan perbandingan skor ratarata BDI pada kelompok eksperimen dan kelompok kontrol:

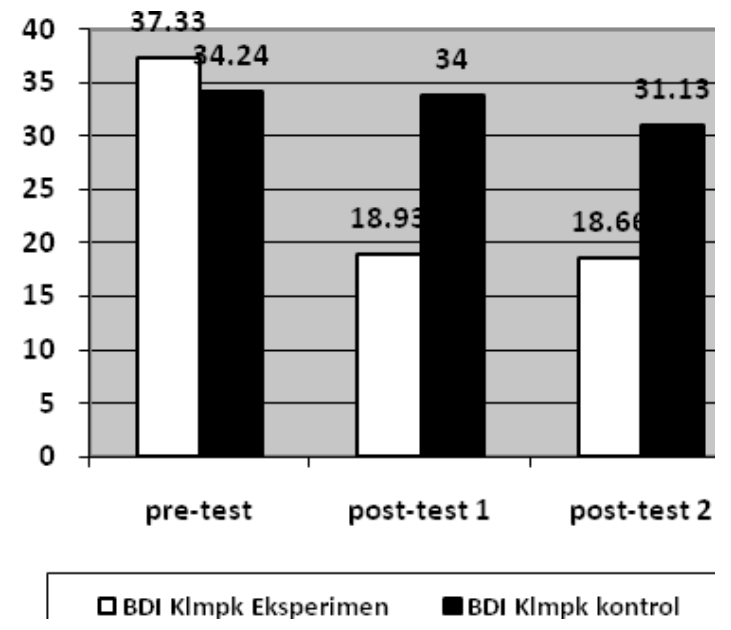

Gambar 1. Grafik perbandingan skor rata-rata BDI pada kelompok eksperimen dan kelompok kontrol.

\section{Created with}




\section{Diskusi}

Berdasarkan paparan hasil diatas, terlihat bahwa terapi membatik secara signifikan mampu menurunkan skor BDI pada posttest 1 secara signifikan, namun tidak signifikan pada posttest 2. Bila kita cermati dalam skor rata-rata kelompok, kategorisasi skor BDI turun dari kategori berat pada pretest menuju kategori ringan pada posttest 1 dan posttest 2 . Hal tersebut membuktikan bahwa meskipun tidak signifikan pada uji posttest 2, namun sbila dikategorisasikan ternyata skor BDI tetap pada kategori saat posttest 1 (ringan).

Hasil tersebut sekaligus menunjukkan bahwa hipotesis yang diajukan dalam penelitian ini diterima, yaitu terapi membatik dapat menurunkan tingkat depresi narapidana. Menurut analisa peneliti, hasil tersebut tidak lepas dari beberapa faktor dalam penelitian seperti pelaksanaan penelitian, subjek penelitian, dan juga pihak Lembaga Pemasyarakatan.

Pelaksanaan penelitian menjadi kunci keberhasilan terapi membatik dalam penelitian ini. Pelasanaan penelitian ini terkait dalam beberapa aspek seperti materi terapi, intensitas dan jadwal terapi, metode terapi, pemilihan fasilitator dan juga dinamika kelompok terapi. Materi dalam pelatihan ini disusun berdasarkan pendekatan teori untuk mengantisipasi dan memberikan pola pikir baru bagi subjek dalam menghadapi depresi dengan mendekati faktor penentunya. Dalam tinjauan pustaka pada bab II dijelaskan bahwa faktor penentu depresi menurut Retnowati (2008) terdapat tiga faktor yaitu sumber daya pribadi, sumber daya sosial dan strategi mengatasi masalah. Sumber daya pribadi dalam terapi ini dikembangkan dengan materi analisa diri. Sumber daya sosial dalam penelitian ini dikembangkan dengan pembentukan dinamika kelompok terapi yang solid. Strategi mengatasi masalah (coping) dalam penelitian ini juga dikembangkan secara fleksibel dan kreatif dalam setiap materi, khususnya materi optimisme.

Selain materi terapi secara inti, pelatihan ini juga memberikan materi tambahan berupa ice breaking dan membangun harapan. Materi ini dimaksudkan dapat mendorong subyek penelitian untuk dapat mengikuti pelatihan dengan perasaan nyaman dan santai, sehingga subyek dapat terlibat sepenuhnya untuk mengikuti jalannya terapi. Kondisi rileks yang diciptakan tetapi tetap serius ini dapat membantu peserta pelatihan untuk tetap dalam kondisi 
optimal, sehingga peserta terapi dapat menggunakan kemampuan berpikirnya dalam taraf optimal.

Intensitas dan jadwal dalam penelitian ini berhasil memberikan efek untuk mereduksi tekanan pada subjek. Hal tersebut tidak terlepas dari jeda pada hari ke IV dan ke VI yang diberikan peneliti untuk mengurangi efek menekan dan juga pengendapan dari materi sebelumnya. Selain hal tersebut, jeda juga memaksimalkan tugas yang diberikan oleh peneliti berupa gambar pola batik.

Metode dengan menggunakan pendekatan suportif dalam penelitian ini mampu memberikan dorongan pada subjek tanpa ada unsur penilaian (Liebmann, 1986; Ballou, 1995). Variasi metode dalam terapi (ceramah, diskusi, latihan atau penugasan, game, presentasi dan juga wawancara individual) berhasil memberikan nuansa lebih hidup, rileks, ceria, menantang tapi santai dan lebih bersemangat selama berlangsungnya terapi sehingga berhasil menurunkan tingkat depresi pada narapidana.

Selain itu metode ini juga dapat mendorong subjek penelitian untuk berlatih memahami ide dan pendapat orang lain, menerima perbedaan, dan mendiskusikan perbedaan atau ketidaksepahaman yang terjadi selama proses terapi. Hal lain yang dicapai dalam metode ini adalah timbulnya keberanian subjek untuk mengemukakan pendapat, kemauan subyek untuk bertanya, keterlibatan subjek dalam memerankan suatu tugas serta keberanian subyek untuk menyampaikan informasi kepada orang lain di depan kelompok. Metode dalam kegiatan ini juga terbukti meningkatkan keterampilan sosial subjek dalam bentuk presentasi, komunikasi dan membangun relasi sosial dengan orang lain dalam forum kelompok.

Pemilihan fasilitator berpengalaman pada materi masingmasing mampu menciptakan iklim pelatihan dengan kebebasan, kenyamanan, penuh keakraban dan keamanan psikologis, serta mampu mendukung dan menghargai subjek dalam setiap keadaan dan kemampuan yang ditunjukkan oleh subjek terapi. Selain peneliti sendiri, pemateri dalam terapi ini adalah Badruzzaman S.Pd. (mentor dan pengkader dalam sebuah organisasi pergerakan mahasiswa) sebagai fasilitator analisa diri, Ahmad Chamim S.S. (budayawan dan pelukis asli Rembang) sebagai fasilitator menggambar dan membuat pola batik serta Santoso Hartono dan Parlan (ahli batik dan pengusaha batik peraih upakarti 2010) sebagai fasilitator dalam praktek pembatikan. 
Dinamika kelompok dalam terapi membatik dipilih dengan mengkategorikan kelompok dalam kategori besar (Juul \& Schuler, 1983; Wallin \& Durr, 2002; Isaksson et al., 2009; Gussak, 2009). Dengan heterogenitas umur, pendidikan, jenis pidana dan lama hukuman, setiap subjek dalam kelompok akan mempelajari perbedaan, jenis masalah dan juga tingkat tekanan sehingga menjadi bahan evaluasi, penerimaan, dan koping bagi setiap subjek.

Subjek penelitiandalam penelitianiniberpengaruhmengingat kriteria subjek ditentukan atas asumsi bahwa subjek memiliki stresor tinggi dalam kehidupannya, seperti keluarga, pekerjaan dan sangsi sosial yang akan diterima. Asumsi tersebut dipredikasi oleh peneliti akan meningkatkan skor gangguan psikologis (Hughes, 2009; Huss, 2009: Gussak, 2009), khususnya depresi. Disisi lain, terdapat faktor yang bukan saja menjadi stresor namun juga sebagai harapan subjek, yaitu keluarga (wawancara dengan seluruh subjek).

Temuan ini tentunya memperlihatkan betapa besarnya pengaruhlingkunganinternal subjek(keluarga) terhadap peningkatan sekaligus penurunan gangguan depresi. Peningkatan atau penurunan tersebut tercermin dalam simtom depresi, seperti perasaan sedih, bersalah, gagal, dan penyalahan terhadap diri sendiri.

Berdasarkan data wawancara kepada seluruh subjek, aktivitas membatik merupakan kegiatan baru, menantang dan menarik untuk dilakukan. Hal tersebut sekaligus mendukung teori bahwa terapi seni (dalam penelitian ini membatik) memiliki tingkat resistensi dari subjek yang lebih kecil daripada terapi verbal lainnya (Malchiodi, 1988; Malchiodi, 2001; Case \& Dalley, 1992). Hal tersebut menurut data wawancara dalam penelitian ini dikarenakan subjek merasa terhibur melakukan hal-hal baru dan juga unik (membatik).

Keberhasilan terapi membatik juga tidak terlepas dari kerjasama dari pihak Lembaga Pemasyarakatan (LP). Pihak LP dengan tangan terbuka memberikan bantuan berupa sarana penunjang berjalannya terapi seperti ruangan terapi, petugas keamanan, dan juga informasi terkait narapidana pada saat seleksi subjek. Semua bantuan dan kerjasama tersebut membuat peneliti nyaman dan bergerak leluasa dalam penelitian dan memilih subjek secara lebih selektif sehingga penelitian dapat berjalan dengan baik sesuai prosedur penelitian.

\section{Created with}




\section{Kesimpulan}

Berdasarkan hasil penelitian, dapat disimpulkan bahwa terapi membatik dapat secara signifikan menurunkan tingkat depresi pada subjek penelitian. Sebagai sebuah pengembangan model terapi (intervensi) baru, jenis terapi membatik masih sangat dinamis untuk dikembangkan dan dimodifikasi pada masa mendatang. Meskipun banyak unsur lain yang kemungkinan berpengaruh dalam proses terapi membatik, hal tersebut telah diantisipasi oleh peneliti dengan menggunakan model eksperimen. Sehingga diharapkan mampu menjadi batasan maksimal proses terapi membatik.

Sebagaimana dijelaskan sebelumnya, bahwa membatik dalam penelitian ini merupakan sebuah terapi ekspresif yang dibuat untuk memfasilitasi subyek dalam sebuah proses penciptaan tanpa menghiraukan estetika didalamnya. Sesuai dengan teori yang telah berkembang sebelumnya, bahwa inti dari terapi seni adalah terletak dalam proses penciptaan tanpa terlalu menghiraukan nilai estetika (Killick \& Schaverien, 1997; Malchiodi, 2003). Sehingga keseluruhan subjek mengaku bahwa dengan membatik mereka bebas berekspresi sesuai dengan kehendak dan selera mereka tanpa takut dinilai. Dalam beberapa kasus (subjek 3, 4, 7 \& 15), membatik juga dapat memfasilitasi mereka untuk tetap merasa aman, mengingat mereka telah kehilangan kepercayaan dari lingkungan terdekatnya. Kenyataan tersebut juga sesuai dengan pendapat Ballou (1995) dan Jarboe (2004) yang menyatakan bahwa seni merupakan media paling aman untuk memfasilitasi komunikasi melalui eksplorasi emosi, pikiran, persepsi, keyakinan, dan pengalaman, khususnya emosi.

Selanjutnya perasaan aman dan bebas tersebut dalam penelitian ini dapat menurunkan gangguan depresi pada subjek penelitian. Namun menurut peneliti, terdapat beberapa faktor lain yang turut membatu membangun kedua perasaan tersebut dalam penelitian seperti pelaksanaan penelitian (materi, metode dan dinamika kelompok), pemilahan subjek penelitian, keluarga subjek dan juga pihak Lembaga Pemasyarakatan. Kesemuanya berkorelasi mewujudkan keberhasilan tujuan penelitian, yaitu turunnya tingkat depresi pada subjek.

Berdasarkan diskusi dari hasil penelitian, peneliti memiliki beberapa saran untuk beberapa pihak, yaitu:

$$
\text { Created with }
$$

$$
\text { n nitro }{ }^{\text {PDF }}
$$


1. Untuk subjek penelitian, diharapkan subjek dapat memanfaatkan kandungan materi dan juga keterampilan menggambar pola batik saat berada pada situasi menekan dan juga membosankan.

2. Untuk pihak lembaga pemasyarakatan:

a. Diharapkan dapat memanfatkan modul terapi membatik untuk dapat diterapkan dalam proses reedukasi, rehabilitasi dan pembinaan narapida.

b. Selain sebagai bentuk terapi, pihak lembaga pemasyarakatan juga dapat memanfaatkan kegiatan membatik untuk pengembangan keterampilan dan wirausaha alternatif.

3. Untuk peneliti selanjutnya:

a. Diharapkan melakukan modifikasi dan penyempurnaan terkait materi danjuga metode terapi untuk mendapatkan hasil yang lebih baik.

b. Melakukan penelitian serupa namun dengan subjek yang lebih variatif.

c. Menggunakan terapi membatik untuk melihat peningkatan aspek positif manusia, seperti harga diri, kreativitas, well being dan lain sebagainya.

d. Melakukan penelitian dalam bentuk eksperimen laboratorium yang benar-benar dapat menjaga pengaruh lingkungan terhadap proses terapi, sehingga hasil terapi dapat betul-betul dipertanggungjawabkan.

4. Untuk profesional dalam psikologi, diharapkan menggunakan terapi jenis ini sebagai intervensi alternatif untuk menurunkan gangguan psikologis.

\section{Daftar Pustaka}

American Psychiatric Assosiations. (2000). Diagnostic and Statistical Manual of Mental Disorders, Fourth Edition. Text Revision. Washington : American Psychiatric Assosiations.

Ballou, M. (1995). Psychologyycaldnteridentions : A Guide To Strategies. Westport, CT: Praeger Publ:-hers. 
Beck, A. T. (1985). Depression : Causes and Treatment. Philadelphia: University of Pennsylvania Press. (publikasi 2006).

Beck, A.T., \& Weishaar, M.E. (1989). Cognitive Therapy. Dalam R.J. Corsini \& D. Weddings (Eds), Curent Psychoterapies (4th $\mathrm{ed}$., hlm. 285-320). Illnois: F.E. Peacock Publishers, Inc.

Bilkser, D., Wiseman, S., \& Gilbert, M. (2006). Managing Depression Related Occupational Disability: Pragmatic Approach. Journal psychiatry, 51(2), 76-78.

Blou, G.M., \& Gullota, T.P. (1996). Adolescents disfungsional behavior : Causes, intervention, and prevention. New York : Sage Publication Inc.

Case, C. \& Dalley, T. (1992). The Handbook of Art Therapy. USA \& Canada: Routledge.

Coleman, V. (1991). Stres - Pencegahan dan Penanggulangannya (Terjemahan). Jakarta: BPK Gunung Mulia.

Creswell, J. W. (1994). Research design: Qualitative and quantitative approaches. Thousand Oaks, CA: Sage.

De Clerq. 1994. Tingkah Laku Abnormal Dari Sudut Pandang Perkembangan. Jakarta: Grasindo.

Fischer, J., \& Corcora, K.J. (2007). Measures for clinical practice and research: couples, families, and children. Oxford: oxford university press.

Greenberger, D. \& Padesky, C. A. (1995). Mind Over Mood: Change How You Feel By Changing The Way You Think. New York: The Guilford Press.

Gussak, D. (2009). The Arts in Psychotherapy Comparing the effectiveness of art therapy on depression and locus of control of male and female inmates. The Arts in Psychotherapy 36, 202-207.

Hawton, K., Salkovskis, P.M., Kirk, J., \& Clark, D. M. (1993). Cognitive Behavior Therapy For Psychiatric Problems: A Practical Guide. New York: Oxford University Press.

Holt, E \& Kaiser, D.H. (2002). The first step series: art therapy for early substance abuse treatment. The Arts in Psychotherapy 36, 245-250.

Horowitz, J.L., \& Garber, J. (2006). The Prevention Of Depression Symptoms In Children And Adolescents: A Meta-Analytic Review. Journal of consulting and clinical psychology, 74(3), 401-415.

Hughes, E.G. (2009). Art Therapy as a Healing Tool for Sub-fertile Women. J Med Humanit 31:27-36.

Huss, E. (2009). "A Coat Of Many Colors" Towards An Integrative Multilayered Model Of Art Therapy. The Arts in Psychotherapy, 36, 154-160.

Isaksson, C., Norlén, A.K., Englund, B., OT, R., Lindqvist, R. (2009). Changes in self-image asseentinl treet paintings. The Arts in Psychotherapy, 36. 304-312. 
Lantz, J. \& Lisa, R. (2003). Play And Art In Existential Trauma Therapy With Children And Their Parents. Human Sciences Press : Contemporary Family Therapy 25(2).

Lazarus, R. S. (1991). Emotion and Adaption. New York: Oxford University Press.

Liebmann, M. (1986). Art therapy for groups a handbook of themes, games and exercises. London: Routledge.

Malchiodi, C. (1988). Bringing art therapy to China. American Journal of Art Therapy, 27, 54-60.

Malchiodi, C. (Ed) (2003). Handbook of Art Therapy. USA: Guildford Press.

Mazure, M. M. (1998). Life Stressors As Risk Faktors In Depression. Clinical Psychology: Science and Practice, 5, 291-313.

Mellings. T.M.B., \& Alden, L. E. (2000). Cognitive Processes In Sosial Anxiety: The Effect Of Self-Focus, Rumination And Anticipatory Processing. Behaviour research and therapy, 38, 243-257.

Morgan, C. (1981). Developing mental health services for local jails. Criminal Justice \& Behavior, 8(3), 259-262.

Muri, S.A. (2007). Beyond the face: Art therapy and self-portraiture. The Arts in Psychotherapy, 34. 331-339.

Retnowati, S. (2008). Sumber daya pribadi sebgai mediator dampak kejadian menekan terhadap munculnya simtom depresi pada remaja. ANIMA. 23, 360-371.

Shadish, W.R., Cook, T.D., \& Campbell, D.T. (2002). Experimental and quasi eksperimental design for generalized causal inference. New York: Hougton Mifflin Company.

Silverstein, B. \& Blumenthal, E. (1997). Depression mixed with anxiety, somatization, and disordered eating: Relationship with genderrole-related limitations experienced by females. Sex Roles, 36, 709724.

Silverstein, B. \& Lynch, A.D. (1998). Gender and depression: The role played by paternal attitudes of male superiority and maternal modeling of gender-related limitations. Sex Roles, 38, 539-555.

Silverstein, B. (2002). Gender difference in the prevalence of somatic versus pure depression: A replication. American Journal of Psychiatry. 159(6) 1051-1052.

Snyder, C. R. \& Lopez, S. J. (2007). Positive Psychology: The Scientific and Practical Explorations of Human Strenghts. Sage Publication: London.

Solso, R. L., Maclin, O. H., \& Maclin, M. K. (2008). Psikologi Kognitif. Surabaya: Penerbit Erlangga.

$$
\text { (n) } \text { nitro }^{\text {PDF }}
$$

PSIKOISLAMIKA, Jurnal Psikoiuyr Islam (JPI) 
Sternberg, R. J. (1997). Patways To Psychology. Florida: Harcourt Brace \& Company.

Sternberg, R. J. (2008). Psikologi Kognitif. Yogyakarta: Pustaka Pelajar.

Suryaningrum, C. (2005). Terapi Kognitif Tingkah Laku Untuk Mengatasi Kecemasan Social. Tesis. Jakarta: Pascasarjana Fakultas Psikologi Universitas Indonesia.

Torres, S., \& Guerra, M.P.(2002). Application Of Narrative TherapyToAnorexia Nervosa: A Study Case. Revista portuguesa de psicossomatica, vol. 4:1, 141-156.

Wallin, K. \& Durr, M. 2002. Creativity and expressive art in social emotional learning. Journal of Reclaiming Children and Youth, 11 (1), 30.

Wells, A., Clark, D. M., Salkovskis, P., Ludgate, J., Hackmann, A., \& Gelder, M. (2007). Sosial Phobia: The Role Of In-Situation Safety Behaviours In Maintaining Anxiety And Negatif Believe (Abstrak). Behavior Therapy, 26, 153-161.

Wilkinson, G. (1992). Depresi. Jakarta: Arcan. 